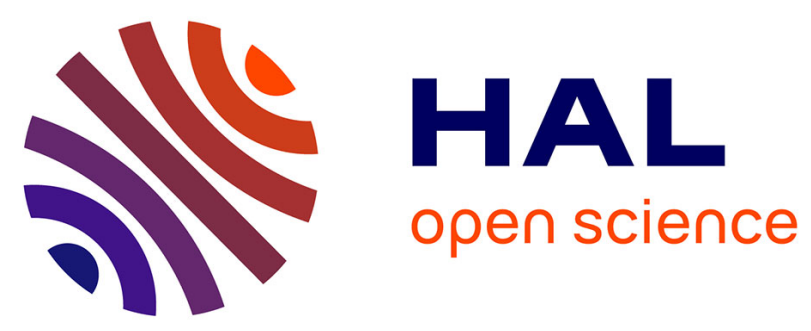

\title{
Authority Beyond State and Tribe in the Early Medieval Maghrib: The Impact of Climate on the Economic, Social and Political Reorganisation of the Maghrib al-Aqșā in the Eighth-Ninth Centuries: The Case of Sijilmāsa (Morocco) \\ Chloé Capel
}

\section{To cite this version:}

Chloé Capel. Authority Beyond State and Tribe in the Early Medieval Maghrib: The Impact of Climate on the Economic, Social and Political Reorganisation of the Maghrib al-Aqșā in the Eighth-Ninth Centuries: The Case of Sijilmāsa (Morocco). Al-Masaq, 2021, 33 (1), pp.47-65. 10.1080/09503110.2020.1868052 . hal-03271749

HAL Id: hal-03271749

https://hal.science/hal-03271749

Submitted on 27 Jun 2021

HAL is a multi-disciplinary open access archive for the deposit and dissemination of scientific research documents, whether they are published or not. The documents may come from teaching and research institutions in France or abroad, or from public or private research centers.
L'archive ouverte pluridisciplinaire HAL, est destinée au dépôt et à la diffusion de documents scientifiques de niveau recherche, publiés ou non, émanant des établissements d'enseignement et de recherche français ou étrangers, des laboratoires publics ou privés. 


\title{
Authority Beyond State and Tribe in the Early Medieval Maghrib : The Impact of Climate on the Economic, Social and Political Reorganisation of the Maghrib al-Aqșā in the Eighth- Ninth Centuries: The Case of Sijilmāsa (Morocco)
}

\author{
Chloé CAPEL
}

Chloé Capel (2021): Authority Beyond State and Tribe in the Early Medieval Maghrib: The Impact of Climate on the Economic, Social and Political Reorganisation of the Maghrib al-Aqșā in the EighthNinth Centuries: The Case of Sijilmāsa (Morocco), Al-Masāq, $33: 1$, 47-65, DOI:10.1080/09503110.2020.1868052

\author{
CONTACT \\ chloe.capel@gmail.com \\ UMR 8167 Orient et Méditerranée - Equipe Islam Médiéval, Paris, France.
}

\begin{abstract}
The rise of Islam in the Maghrib al-Aqșā in the eighth and ninth centuries and the simultaneous onset of deep and lasting political, economic, cultural and social upheavals across the region have led historians to focus on Islamisation as the principal cause of this revolution. This article will explore the possible contribution of environmental factors to economic change, and consequently to social and political development. This discussion relates to the field of historical climatology which has been limited in Africa, and especially in the western Maghrib. It focuses on a case study of the caravan city of Sijilmāsa (Morocco) and argues that an important climate oscillation between the eighth and ninth centuries may have been a decisive factor in its foundation. Finally, it suggests that this climate fluctuation may have been a driving factor in the urbanisation that the Maghrib al-Aqșā experienced more widely in this period.
\end{abstract}

\section{KEYWORDS}

Archaeology; Climatology; Environment; Oasis; Agriculture; Urbanisation

\section{Introduction: Rewriting the History of the Maghrib through Historical Climatology}

The spread of Islam in North Africa initiated a series of deep and lasting political, economic, cultural and social upheavals which remain poorly understood today in the western Maghrib, for which the last centuries before Islam remain incompletely documented, thus depriving historians of an accurate diachronic understanding of events. Innumerable social transformations - even revolutions - throughout North Africa have been attributed to the arrival of Islam and the advent of a new cultural universe: linguistic upheavals with the introduction of the Arabic language, ${ }^{1}$ technological breakthroughs with the development of new agricultural practices, ${ }^{2}$ territorial transformations with urban reorganisation, ${ }^{3}$

\footnotetext{
1 Peuplement et arabisation au Maghreb occidental : Dialectologie et histoire, ed. Patrice Cressier, Jordi Aguadé, and Angeles Vicente (Madrid: Casa de Velázquez, 1998).

${ }^{2}$ Andrew Watson, Agricultural Innovation in the Early Islamic World: The Diffusion of Crops and Farming Techniques 700-1100 (Cambridge: Cambridge University Press, 1983).

${ }^{3}$ Corisande Fenwick, "Early Medieval Urbanism in Ifrīqiya and the Emergence of the Islamic City", in El mundo de las ciudades en la Península Ibérica y en el norte de África (siglos IV-IX), ed. Sabine Panzram and Laurent Callegarin (Madrid: Casa de Velázquez, 2018), pp. 283-304.
} 
economic changes with the introduction of silver coinage ${ }^{4}$ and dramatic political restructuring with the emergence of independent Islamic emirates and imamates. ${ }^{5}$ It is clear that profound reconfiguration occurred in North Africa in the eighth and ninth centuries, and it falls to historians and archaeologists to explain the conditions that led to it.

The clear chronological correlation between the spread of Islam in North Africa and the many transformations that the region underwent at the same time, explains why scholarship has so frequently attributed these developments to Islamisation. But correlation need not imply causation and, for decades, studies in this field may have overestimated the importance of Islam to these evolutions. In line with recent developments in scholarship on the Islamic Maghrib over the past twenty years, one should consider other parameters, particularly endogenous ones, which may have precipitated social transformation, and in some cases may have begun before the arrival of Islam. Indeed, several recent studies have begun to challenge the central role of Islamisation in the transformation of North Africa at the end of the first millennium, especially in the field of agricultural "revolutions" and urban upheavals. ${ }^{7}$ This article takes a similar perspective by exploring the role played by environmental factors, particularly climate, in the evolution of new economic, and then social and political systems, during the eighth and ninth centuries. It draws together recent work in climatology which suggest that the western Maghrib experienced a significant climate change around the eighth and ninth centuries, and argues that this fluctuation had a serious influence on the environment and on the reorganisation of early medieval societies at the dawn of Islam. The present article does not intend, however, to present a regional synthesis of medieval historical climatology in the Maghrib a subject that is still in its infancy - but rather is an exploratory discussion focused on the oasis and city of Sijilmāsa, the most important Saharan trading hub in the Maghrib al-Aqșā.

\section{The Challenge of Historical Climatology in North Africa}

The development of historical climatology in North Africa is hampered by a long historiographical debate and by substantial methodological difficulties. But in spite of these obstacles, environmental and climate data deserve our full attention as they offer new perspectives on historical periods for which few written sources exist, particularly in the western Maghrib.

\section{Brief state of the art}

Historical climatology - the climate history of the Late Holocene (c. 1000 $\mathrm{BC}$ to the present) - is a young discipline, particularly when compared with welldeveloped research by prehistorians and palaeontologists on the climate of the Pleistocene and Early Holocene. Indeed, it is only in the last few decades that climatologists,

\footnotetext{
${ }^{4}$ Elisabeth Savage and Adonn Gordus, "Dihrams for the Empire", in Genèse de la ville islamique en al-Andalus et au Maghreb occidental, ed. Patrice Cressier and Mercedes García-Arenal (Madrid: Casa de Velázquez, 1998), pp. 377-402.

${ }^{5}$ Hichem Djaït, La fondation du Maghreb islamique (Sfax: Amal Editions, 2004).

${ }^{6}$ Michael Decker, "Plants and Progress: Rethinking the Islamic Revolution", Journal of World History 20 (2009): 187-206.

${ }^{7}$ Corisande Fenwick, "From Africa to Ifrīqiya: Settlement and Society in Early Medieval North Africa (650-800)", Al-Masāq 25 (2013): 9-33.
} 
palynologists, geologists and geochemists have become interested in recent climate variations, motivated by the relevance of these studies for understanding current global warming. ${ }^{8}$ Since the mid-nineteenth century, historians and geographers, especially in the European field, have, of course, also reflected on the possible role of climatic fluctuations in other historical changes, but have rarely been able to discuss these issues convincingly due to the paucity of adequate environmental data. ${ }^{9}$ Historical climatology relies above all on sedimentary and palynological analyses of high mountain glaciers, pack ice and ocean and lake soils. It then uses statistical methods to produce global climate simulations and models that are computed from discontinuous data collected over a range of temporal and spatial scales. ${ }^{10}$ As a result, on the African continent, as elsewhere in the world, climatology is, for methodological reasons, the prerogative of biologists, geologists, climatologists and mathematicians, and has only been partially integrated within the humanities and social sciences. Yet climate indicators - also called proxies - that can be used for historical periods are numerous and diverse (including sedimentology, dendrology, palynology) and, thanks to $\mathrm{C} 14$ dating, offer a chronological accuracy that is usually much superior to those available for prehistoric periods, thus meeting the requirements of historians. But if specialists in European and Mediterranean medieval history increasingly integrate information from, and collaborate with, climatologists, ${ }^{11}$ this has yet to systematically occur in the western Maghrib. As a result, most of the climatic studies in this region still depend on the contributions of climate specialists, whose conclusions, which are obviously pertinent from a purely climatic point of view, may have substantial weaknesses in terms of their historical interpretations. ${ }^{12}$ Consequently, such studies have rarely satisfied specialists in ancient and medieval societies, who often neglect them, rather than seeking to exploit the important primary data that they reveal. ${ }^{13}$

The continuing disenchantment of some historians and archaeologists with climatology in the first millennium CE deserves explanation, particularly in contrast to the integration of such approaches in studies of prehistory since the 1950s. The pioneers of historical climatology were the French scholar Emmanuel Le Roy Ladurie and the British historian Hubert Lamb in the late 1960s. Their analyses were based on the data available at that time, that is to say on crossreferencing historical sources with hundredyear syntheses of thermal and hydrometric records provided by their colleagues from the natural sciences. The inaccuracy of the written sources and the shallow

\footnotetext{
${ }^{8}$ Rudolf Brázdil, Christian Pfister, Heinz Wanner, Hans Von Storch, and Jürg Luterbacher, "Historical Climatology in Europe: The State of the Art", Climatic Change 70 (2005): 363-430, pp. 363-70; Heinz Wanner et al., "Mid- to Late Holocene Climate Change: An Overview", Quaternary Science Review 27 (2008): 1791-1828, p. 1792.

9 Jean-Baptiste Fressoz and Fabien Locher, "Modernity's Frail Climate: A Climate History of Environmental Reflexivity", Critical Inquiry 38/3 (2012): 579-98.

${ }^{10}$ Brázdil et al., "Historical Climatology", 363-70; Wanner et al., "Mid- to Late Holocene Climate Change", 1792, 1811.

${ }^{11}$ Histoire et nature: Pour une histoire écologique des sociétés méditerranéennes (Antiquité, Moyen-Âge), ed. François Clément (Rennes: Presses Universitaires de Rennes, 2011).

${ }^{12}$ As a simple example - but this is far from an isolated reference - in one of the few articles devoted to climatic variations identified in Morocco during historical periods, subtitled "A 2000-Year History of Land Use in Southern Morocco", the team of scientists from the German oceanographic centre Marum (Bremen), led by Helen McGregor, takes very large historical shortcuts, particularly in referring to an "Arab invasion" (with some references to Michel Brett's work of the early 1990s) at the time of the conquest of the Maghrib by Umayyad troops (Helen V. McGregor, Lydie Dupont, Jan-Berend W. Stuut, and Holger Kuhlmann, "Vegetation Change, Goats, and Religion: A 2000-Year History of Land Use in Southern Morocco", Quaternary Sciences Reviews 28 (2009): 1434-48, p. 1444).

${ }^{13}$ Philippe Leveau, "Les historiens, le petit âge glaciaire et les lanceurs d'alerte: Une contribution à la réflexivité historienne", Méditerrannée 122 (2014): 201-12.
} 
historical depth of the environmental data consequently limited their reflections, but their works were founding milestones of the discipline. Le Roy Ladurie rejected the view that the climate could have a deterministic effect on social change, while Lamb argued the opposite: these two distinct paradigmatic positions still underpin the two major currents of thought in historical climatology. ${ }^{14}$ At that time, historical climatology was not yet one of the concerns of palaeoclimatologists: only in the 1980s, and especially the 1990s, did research finally shift to more recent periods - in part due to the influence of studies on climate change during the industrial period. Collections of environmental data became common, particularly in the fields of dendrology, palynology and stable isotopes, and new statistical simulations also made it possible to propose long-term climate models. ${ }^{15}$ Despite these advances, the 2000s marked a slowdown in the discipline due to the development of historical arguments against deterministic effects of climate on human societies. ${ }^{16}$ These recent scholarly tensions explain some of the failure of classical and medieval studies of Africa to incorporate questions of climate and the reason why research on the historical climate of the Late Holocene in Africa remains the preserve of climatologists rather than historians. ${ }^{17}$

In earlier scholarship, the discussion of historical climate fluctuations in the Maghrib was largely focused on issues of Roman agricultural exploitation in the Sahara and Steppe. ${ }^{18}$ Yet North Africa - with the exception of some regions of Ifriqiya ${ }^{19}$ - remains a terra incognita in terms of modern historical climatology. "The Mediterranean still has only one shore", ${ }^{20}$ to use a phrase from a recent special issue of Méditerranée devoted to the historical climatology of the Little Ice Age (fourteenth-eighteenth centuries). The different regions of the globe are indeed unequally covered by climate studies and the whole of the African continent has largely been excluded from analysis. While issues of human resources, research infrastructure and cost partly explain this, there are also major methodological obstacles to the study of historical climatology in some parts of Africa, especially in its arid regions. Indeed, research is methodologically limited here by the absence of glaciers or peat bogs, which are two of the main sources of proxies in Europe, and by its dry climate, which considerably hinders palynological studies. However, the study of the Late Holocene climate is not a total impossibility north of the Sahara: the Atlas ranges are particularly suitable regions for climate studies because they can provide researchers with a wide range of indicators, particularly in the context of lacustrine and dendrological studies. Over the past fifteen years or so, a large volume of research in historical climatology, particularly by geoarchaeologists, has focused on the Mediterranean. The central concern has been to test the validity in this

\footnotetext{
14 Hubert Lamb, "The Early Medieval Warm Epoch and Its Sequel", Palaeogeography, Palaeoclimatology, Paleoecoly 1 (1965): 13-37; idem, Climate: Present, Past and Future, volumes I-II (London: Methuen, 1972-1977); Emmanuel Le Roy Ladurie, L'histoire du climat depuis l'an mil (Paris: Flammarion, 1967); Pascal Acot, Histoire du climat: Du Big Bang aux catastrophes climatiques (Paris: Perrin, 2003), pp. 149-54.

${ }^{15}$ Brázdil et al., "Historical Climatology", 374-5, 383-6.

${ }^{16}$ Leveau, "Les historiens".

17 Brázdil et al., "Historical Climatology", 367-70.

${ }^{18}$ Philippe Leveau, "Climat, sociétés et environnement aux marges sahariennes du Maghreb: Une approche historiographique", in La frontière méridionale du Maghreb: Approches croisées (Antiquité-Moyen-Âge), ed. Stéphanie Guédon [Scripta Receptoria, volume XIII] (Bordeaux: Ausonius Editions, 2018), pp. 19-105, esp. 39-55.

${ }^{19}$ Philippe Leveau, "L'environnement de l'Afrique dans l'Antiquité: Climat et société, un état de la question", Ikosim 5 (2016), pp. 57-75.

20 "La Méditerranée n'a qu'une rive". Jean-Michel Carozza, Benoît Devillers, Nick Marriner, and Christophe Morhange, "Introduction", Méditerranée 122 (2014): 3-9, p. 5.
} 
region of the models of the Medieval Climate Optimum and the Little Ice Age, which were developed in studies of central and northern Europe. This has led to an increase in studies in southern Europe, particularly in Spain, whose shores are very close to those of North Africa, but also in Morocco, especially in the Atlas Mountains. $^{21}$ Thus, to date, some twenty articles about the Moroccan climate over the last two millennia have been published. ${ }^{22}$ Almost all these academic studies fall within the sphere of natural sciences and remain underexploited by ancient and medieval historians.

\section{The Maghrib between Late Antiquity and the early Middle Ages: An overview of current knowledge of the climate.}

The majority of studies of the historical climatology of Morocco have been based on the analysis of dendrological data series collected over the last forty years: the majority of these are from Atlas cedar trees, whose growth patterns are particularly affected by climate variations. ${ }^{23}$ More recently, dendrological proxies from other species, such as oak or pine, have been collected, making it possible to cover larger areas. ${ }^{24}$ However, these datasets do not allow scholars to go back beyond the eleventh century, to which the earliest dated trees have been identified. Some (rare) sedimentological analyses in endorheic lacustrine contexts or in wādī soils have been carried out to address this issue. ${ }^{25}$ However, the chronological accuracy is less than that offered by dendrochronology-based modelling - where events can be dated to the nearest decade - and the historian must be content here with ranges expressed in centuries. The most advanced research

\footnotetext{
${ }^{21}$ Carozza et al., "Introduction", 4-5; Jürg Luterbacher et al., "A Review of 2000 Years of Paleoclimatic Evidence in the Mediterranean", in The Climate of the Mediterranean Region: From the Past to the Future, ed. Piero Lionello (Amsterdam: Elsevier, 2014), pp. 87-186, esp. 99-102.

${ }^{22}$ A comparable number of primarily Moroccan, American and British unpublished university dissertations also exist but could not be consulted.

${ }^{23}$ André Berger, Joël Guiot, L. Mathieu, and André Munaut, "Tree-Rings and Climate in Morocco", Tree-Ring Bulletin 39 (1979): 61-75; André Munaut, André Berger, Joël Guiot, and L. Mathieu, "Dendroclimatological Studies on Cedars in Morocco", in Evolution des atmosphères planétaires et climatologie de la terre: Colloque international - Nice, 16-20 octobre 1978, ed. D. Gautier, R. Lesgards, and M. Aubry (Toulouse: CNES, 1979), pp. 373-9; Claudine Till and Joël Guiot, "Reconstruction of Precipitation in Morocco since 1100 A.D. Based on Cedrus Atlantica Tree-Ring Widths", Quaternary Research 33 (1979): $337-$ 51; Nabil Chbouki, Charles Stockton, and Donald Myers, "Spatio-Temporal Patterns of Drought in Morocco", International Journal of Climatology 15 (1995): 187-205; Mary Glueck and Charles Stockton, "Reconstruction of the North Atlantic Oscillation", International Journal of Climatology 21 (2001):1453-65; Jan Esper, David Frank, Ulf Büntgen, Anne Verstege, Jürg Luterbacher, and Elena Xoplaki, "Long-Term Drought Severity Variations in Morocco", Geophysical Research Letters 34/17 (2007): L17702. For references to unpublished academic work see: Rachid Ilmen, Abdelhakim Sabir, and Mohamed Benzyane, "Reconstruction dendroclimatique de la variation de température moyenne avril-juillet depuis 1776 AD dans le Moyen Atlas, Maroc", Journal of Material and Environmental Sciences 1 (2014): 167-76, p. 168

${ }^{24}$ Ramzi Touchan, Kevin Anchukaitis, David M. Meko, Mohamed Sabir, Said Attalah, and Ali Aloui, "Spatiotemporal Drought Variability in Northwestern Africa over the Last Nine Centuries", Climate Dynamics 37/1-2 (2011): 237-52, pp. 238-9; Joël Guiot, "Variations de la température et des sécheresses en région méditerranéenne depuis 1000 ans", in Des climats et des hommes, ed. Jean-François Berger (Paris: La Découverte, 2012), pp. 405-15, esp. 407-9, 411).

${ }^{25}$ Henry F. Lamb, Ulrich Eicher, and Roy Switsur, "An 18000-Year Record of Vegetation, Lake-Level and Climatic Change from Tigalmamine, Middle-Atlas, Morocco", Journal of Biogeography 16 (1989): 65-74; Henry F. Lamb and Sander van der Kaars, "Vegetational Response to Holocene Climatic Change: Pollen and Palaeolimnological Data from the Middle Atlas", Morocco Holocene 5 (1995): 400-8; Ingeborg Soulié-Märsche, Abdelfattah Benkaddour, Najat El Khiati, Pierrette Gemayel, and Mohammed Ramdani, "Charophytes: Indicateurs de paléobathymétrie du lac Tigalmamine (Moyen-Atlas, Maroc)", Geobios 41 (2008): 435-44; Sébastien Détriché, Jean-Gabriel Bréhéret, Hamid Zarki, Louhcine Karrat, Jean-Jacques Macaire, and Michel Fontugne, "Late Holocene Palaeohydrology of Lake Afourgagh (Middle-Atlas, Morocco) from Deposit Geometry and Facies", Bulletin de la Société Géologique de France 179 (2008): 41-50; Sébastien Détriché, Jean-Gabriel Bréhéret, Ingeborg SouliéMärsche, Louhcine Karrat, and Jean-Jacques Macaire, "Late Holocene Water Level Fluctuations of Lake Afourgagh (Middle-Atlas Mountains, Morocco) Inferred from Charophyte Remains", Palaeogeography, Palaeoclimatology, Palaeoecology 283/3-4 (2009): $134-47$.
} 
in this field is an analysis carried out on diatoms stratigraphically collected from the soils of Lake Sīd $\overline{1}$ 'Alī in the Middle Atlas. These diatoms - of which the various species are characteristic of the lacustrine depths in which they develop - are used to estimate the bathymetric variations of the lake and thus to assess the dryness of the climate. ${ }^{26}$ The work at Lake Sīdī 'Alī- broadly confirmed by most of the other sedimentary studies in the Atlas - has suggested that the early first millennium was synonymous with drought, with an almost complete disappearance of the lake, passing in three centuries from a depth of $11 \mathrm{~m}$ to a depth of about $1 \mathrm{~m}$. Before the end of Antiquity, the level of the lake rose progressively to reach a depth of $7 \mathrm{~m}$, a level around which it stabilised, with a low amplitude of low-water periods, until about the year 1000, when it began to undergo a new and lasting period of drought, extending until modern times. Therefore, this regular supply of the lake throughout Late Antiquity and the early Middle Ages very likely indicates a period of relative humidity in the second half of the first millennium, much higher than in either the imperial or medieval phases. However, during this period it should be noted that there was a short moment of substantial drying-out, lasting from one to two centuries, marked by a drop in the lake level of about $3 \mathrm{~m}$, somewhere around the seventh-tenth centuries. It is precisely this significant break in climate patterns, which is only visible through the study of Lake Sīdi 'Alī, among sedimentary studies carried out in Morocco, that seems worthy of note here, since it seems to be contemporaneous with the spread of Islam in the region.

This sedimentary study is the only published analysis of historical climatology that has produced specific data about the early medieval Maghrib alAqșā; other investigations deal with the whole medieval period without differentiation. It therefore remains difficult to assess whether there was a dry period of around a century at the same time as Islam arrived in the region. Moreover, while lake surface variations can mostly be attributed to natural climate conditions, the impact of human activities, particularly agriculture or land clearance, should not be excluded as factors contributing to these fluctuations. Indeed, the Lake Sīdī 'Alī study reveals that soils in the earlier (protohistorical?) periods of this sequence display distinctive eutrophication marks (enrichment of water in mineral salts leading to ecological imbalances), which suggest that some fluctuations of the lake level may be related to humandriven ecological changes. ${ }^{27}$ In the specific case of the lowering of the lake level around the eighth-tenth centuries - where, however, no evidence of eutrophication has been found - the coincidence of this event with the arrival of Islam may thus imply a complex cause-and-effect relationship between these phenomena.

There are compelling reasons to think that this deterioration over one to two centuries was not a local and anthropic phenomenon, but was a climate event of some magnitude that affected all the Atlantic regions. The vast majority of Morocco's territory is located at the junction of the oceanic climatic zone and the Saharan zone; the Mediterranean sphere has only marginal influence in this part of the extreme west of Africa. ${ }^{28}$ Moroccan rainfall

\footnotetext{
${ }^{26}$ Philip Barker, Neil Roberts, Henry Lamb, Sander van der Kaars, and Abdelfattah Benkaddour, "Interpretation of Holocene Lake-Level Change from Diatom Assemblages in Lake Sidi Ali, Middle Atlas, Morocco", Journal of Paleoclimnology 12 (1994): 223-34.

${ }^{27}$ Barker et al., "Holocene Lake-Level Change", 231-2.

${ }^{28}$ Kai Born, Michael Christoph, Andreas Fink, Peter Knippertz, Heiko Paeth, and Peter Steph, "Moroccan Climate in Present and Future: Combined View from Observational Data and Regional Climate Scenarios", in Climatic Changes and Water Resources in the Middle East and North Africa, ed Fathi Zereini and Heinz Hötzl (Berlin-Heidelberg: Springer, 2008), pp. 29-45, esp. 33-5.
} 
is therefore subject to both the position and movements of Saharan high-pressure systems and of oceanic cyclonic activities, in both north-south and west-east directions. The climatic variations affecting the western Maghrib between Antiquity and the Middle Ages are thus mainly due to the displacement and power of the Azores High (a semi-permanent anticyclonic region with relatively consistent high pressure), whose very southerly position during Late Antiquity was displaced to the north by atmospheric pressure effects from the end of the millennium, blocking the arrival of ocean rains on the western Maghrib. ${ }^{29}$ This phenomenon also explains the rise of Atlantic humid air masses over the Mediterranean region. These variations in atmospheric pressure originated in the temperature variations of oceanic water masses and their circulation dynamics and are therefore only the very localised expression of climate phenomena of much greater magnitude. The climate regime governing all atmospheric events and ocean dynamics in the North Atlantic is referred to as the North Atlantic Oscillation (NAO). ${ }^{30}$ The behaviour of this oscillation, primarily influenced by solar activity, is therefore largely responsible not only for the climate fluctuations of the western Maghrib since Antiquity but also for those of western Europe and North America whose climate models do indeed show similar trends to the Moroccan one, proving the common, and global, origin of the phenomenon despite very different local effects in climate.

These models shows three clear main phases: an ancient sequence marked by a positive (northward) thrust of the oscillation, ending around the third century; a phase of negative (southward) thrust corresponding to Late Antiquity and the early Middle Ages, with a significant anomaly around the seventh-ninth centuries; finally, a rapid transition to a new positive thrust initiated around the year 1000. ${ }^{31}$ Thus, the positive thrust at the beginning of the first millennium resulted in a mild and relatively humid climate over western Europe, ${ }^{32}$ which occurred at the same time as a slight deterioration on the southern shore of the Mediterranean, demonstrated in the study of Lake Sīd 'i 'Alī. The negative thrust that followed, which lasted until the end of the millennium, triggered a gradual but distinct hydric deterioration that is now well characterised in the northern Mediterranean, ${ }^{33}$ while in the western Maghrib, a much more favourable climate would take over. Within this period, the anomaly that occurred between 750 and 950 - perhaps as a consequence of an increase in volcanic activity worldwide caused a cold wave and a

\footnotetext{
${ }^{29}$ Esper et al., "Long-Term Drought".

${ }^{30}$ Mary Glueck and Charles Stockton, "Reconstruction of the North Atlantic Oscillation, 1423-1983", International Journal of Climatology 21 (2001): 1453-65.

${ }^{31}$ Gerard Bond, Bernd Kromer, Juerg Beer, Raimund Muscheler, Michael N. Evans, William Showers, Sharon Hoffman, Rusty Lotti-Bond, Irka Hajdas, and Georges Bonani, "Persistent Solar Influence on North Atlantic Climate during the Holocene", Science 294 (2001): 2130-6, p. 2133; Valérie Trouet, James D. Scourse, and Christoph Raible, "North Atlantic Storminess and Atlantic Meridional Overturning Circulation during the Last Millenium: Reconciling Contradictory Proxy Records of NAO Variability", Global and Planetary Change 84-5 (2012): 48-55, p. 52.

${ }^{32}$ Mireille Provensal, Jean-François Berger, Jean-Paul Bravard, Pierre-Gil Salvador, Gilles Arnaud-Fasseta, Hélène Bruneton, and Anne Vérot-Bourrély, "Le régime du Rhône dans I'Antiquité et au haut Moyen Âge", Gallia 56 (1999): 1-32, p. 30; JacquesLéopold Brochier, Jean-Luc Borel, and Jean-Claude Druart, "Les variations paléoenvironnementales de 1000 avant à 1000 après J.C. et la question des optima climatiques de l'Antiquité tardive et du moyen âge sur le piémont des Alpes du nord à Colletière, lac de Paladru, France", Quaternaire 18/3 (2007): 253-70, p. 265; Michael McCormick et al., "Climate Change during and after the Roman Empire: Reconstructing the Past from Scientific and Historical Evidence", Journal of Interdisciplinary History 43/2 (2012): 169-220, pp. 174-80.

33 Brochier, Borel, and Druart, "Variations paléoenvironnementales", 267; Carlo Giraudi, Michel Magny, Giovanni Zanchetta, and Russel N. Drysdale, "The Holocene Climatic Evolution of Mediterranean Italy: A Review of the Continental Geological Data", Holocene 21 (2011): 105-15; McCormick et al., "Climate Change", 185-6, 191-6.
} 
rise of humidity in north-western Europe - the so-called "Carolingian cold"34 while southern Europe was at the same time experiencing a temporary return to aridity. ${ }^{35}$ It would therefore seem that the anomaly identified by the analysis of Lake Sìd ' 'Alì , approximately dated to the seventh-tenth centuries, is confirmed by this correlation with European climate events, and can be narrowed down chronologically to 750-950 AD to match the so-called "Carolingian" climate anomaly.

\section{2 - A Study of Moroccan Environmental History between Late Antiquity and the Early Middle Ages: The Case of Tāfīlālt}

The second step of any study in historical climatology is to determine the significance of possible environmental changes caused by climate oscillations. Thus, if there was a major fluctuation in the western Maghrib around the eighthninth centuries, it is necessary to determine the consequences of this shift for the environment, subsistence economies and social organisation. Unfortunately, a paucity of archaeo-environmental studies for the western Maghrib mean that it is still difficult to determine the impact of the climate anomaly of the eighth-ninth centuries at the regional level. The remainder of the article therefore focuses on the case study of the Saharan plain of Tāfìlālt, the area where the caravan city of Sijilmāsa ${ }^{36}$ was founded at some point between the eighth and ninth

\footnotetext{
${ }^{34}$ Michael McCormick, Paul E. Dutton, and Paul A. Mayewski, "Volcanoes and the Climate Forcing of Carolingian Europe, A.D. 750-950", Speculum 82 (2007): 865-95.

${ }^{35}$ McCormick et al., "Climate Change", 200-1; Julien Azuara, Nathalie Combourieu-Nebout, Vincent Lebreton, Florence Mazier, S.D. Müller, and Laurent Dezileau, "Late Holocene Vegetation Changes in Relation with Climate Fluctuations and Human Activity in Languedoc (Southern France)", Climate of the Past 11 (2015): 1769-84, p. 1779; Aline Durand and Philippe Leveau, "Farming in Mediterranean France and Rural Settlement in the Late Roman and Early Medieval Periods: The Contribution from Archaeology and Environmental Sciences in the Last Twenty Years", in The Making of Feudal Agriculture, ed. Miguel Barceló and François Sigaut [The Transformation of the Roman World, volume XIV] (Leiden: Brill, 2004), pp. 177-253, esp. 181-4.

${ }^{36}$ The first modern notes relating to Sijilmāsa were produced by French soldiers involved in the occupation of the Maghreb (see Hyacinthe Dastugue, "Quelques mots au sujet de Tafilet et de Sidjilmassa", Bulletin de la Société de Géographie, 5 ème série, 13/1 [1867]: 337-80; Ernest Mercier, "Sidjilmassa selon les auteurs arabes", Revue Africaine 11 [1867]: 233-42, 274-84; Henri Fournel, Les Berbers: Etude sur la conquête de l'Afrique par les Arabes, volume II [Paris: Ernest Leroux, 1881], pp. 22-4) and then from the 'Alawite chronicler al-Nașīī (al-Nașīīi, Kitāb al-istiqșā li-akhbār duwal al-Maghrib al-aqșā, volumes I-III [Cairo: alMu'allif, 1894-1895] I:55-8, II:101, III:142-5, 171-3, 202, 207). The first critical studies on the city, which drew upon a range of historical sources, came from a circle of orientalist scholars working during the Protectorate (see Georges Marçais, Les Arabes en Berbérie du XIe au XIVe siècle [Paris: Ernest Leroux, 1913] pp. 224, 370, 382-4, 393-8, 564; Georges Colin, "Sidjilmâsa", in The Encyclopedia of Islam, volume IV [Leiden/Paris: Brill/Picard 1934]; Charles Pellat, "Midrār", in The Encyclopedia of Islam, volume VI [Leiden: Brill, 1991], 1037; Henri Terrasse, Histoire du Maroc des origines à l'établissement du Protectorat français, volumes III [Casablanca: Frontispice, 1949-1950], I:169, 173-4, 186, 203-4, 220, II:48, 214). The major studies dedicated to the history of the city were written by Moroccan historians after independance (Larbi Mezzine, "Sur l'étymologie du toponyme Sijilmasa", Hespéris-Tamuda 22 [1984]: 19-25; idem, Le Tafilalt: Contribution à l'histoire du Maroc auX XVII et X VIII' siècles [Rabat: Faculté des Lettres et des Sciences Humaines, 1987]; Mohamed Mellouki, "Contribution à l'étude de l'histoire des villes médiévales du Maroc: Sigilmassa des origines à $668(\mathrm{H}) / 1269$ (J.-C.)", PhD Thesis, Université Aix-Marseille I, 1985; Mahmud Ismā'îl 'Abd alRāziq, Al-khawārij fỉ bilād al-Maghrib ḥattā muntașaf al-qarn al-rābi" al-hïrī [Casablanca: Maktabat al-Hurriyya al-Hadịtha, 1985] pp. 109-43, 210-29; Muhammad al-Khațīb, Duwaylat Banī Midrār 140-296 H/757-908 M. [Cairo: 1989]; Hasan 'Alawī, Sijilmāsa wa-iqlīmuhā fì l-qarn al-thāmin al-hïrī [Rabat: Ministère des Affaires Islamiques, 1997]). Outside Morocco, the few studies of Sijilmāsa mainly focus on the Saharan dimension of the site, rather than its Maghrib history (Daniel McCall, "The Traditions of the Founding of Sijilmassa and Ghana", Transactions of the Historical Society of Ghana 5/1 [1961]: 3-32; JeanMarie Lessard, "Sijilmassa: La ville et ses relations commerciales au XI siècle d'après el-Bekri", Hespéris-Tamuda 10 [1969]: 536; Nehemia Levtzion, "The Jews of Sijilmasa and the Saharan Trade", in Communautés juives des marges sahariennes du Maghreb, ed. Michel Abitbol [Jerusalem: Institut Ben-Zvi and Université Hbraïque, 1982], pp. 253-63; John Wright, "Sijilmasa: A Saharan Entrepot", Morocco: The Journal of the Society for Moroccan Studies 1 [1991]: 7-19). Within this work, the remarkable scholarship of D. Jacques-Meunié devoted to the history of all the Saharan regions of Morocco is particularly worthy of note: in his book, Sijilmāsa is not only considered in detail, but also questioned from the standpoint of regional history, thus delivering what remains one of the best historical reflections on the city to date: D. Jacques-Meunié, Le Maroc saharien des origines à 1670 (Paris: Klincksieck, 1982), pp. 58, 62, 66-7, 153, 170, 184, 195-7, 201-7, 211, 226, 235-43, 256-8, 264-72, 283, 287-98, 335-7, 455-6, 741. Since the 1990s, Sijilmāsa has no longer really drawn the attention of historians, mainly because of the limited
} 
centuries $^{37}$.

\section{The Täfilālt Plain and Sijilmāsa: environmental and climate data assessment}

The Tâfîlālt plain is an arid flat area nestled at the southern foot of the High Atlas range, between the Algerian hammādas and the last reliefs of the AntiAtlas. It forms a vast depression with desolate and sandy landscapes thus located on the northern edge of the Sahara (see Figures 1 and 2). The bowl-shape morphology of this alluvial basin is the result of a long erosion sequence that occurred during the Quaternary period and gradually cut into the surrounding relief that now overlooks this flat and steep-sided region on all sides. This depressed geological facies explains why numerous wādīs formed in the surrounding mountains drain into the Tāfîlālt plain. The most important of these are the $Z_{\overline{1}} \mathrm{z}$ and the Gheris, two rivers with a permanent flow, which originate about $150 \mathrm{~km}$ to the northwest and nearly $3500 \mathrm{~m}$ above sea level, in the middle of the Atlas, at the foot of the snowy peaks of Jebel 'Ayyāshī. The Tāfìlālt plain is the unique and narrow outlet of a vast catchment area of nearly $20,000 \mathrm{~km}^{2}$, half of which is located in the High Atlas, a generously watered region where annual rainfall often exceeds $600 \mathrm{~mm}:^{38}$ this is why, although located in a desert environment, where rainfall is negligible, Tāfîlālt benefits from exceptional water resources, both underground and surface, especially during the spring snowmelt, which redistributes downstream part of the winter accumulation of precipitation from high altitudes (Figure 3). These resources make the Tâfīlālt plain - the final point in the catchment area reached by the floods of the Zīz and Gheris before they vanish into the desert sands - a natural ecological refuge which is conducive to intensive oasis agriculture (see Figure 4). ${ }^{39}$

To date, no studies on the recent climate of Tâfîlālt have been carried out. ${ }^{40}$ It is, however, possible to link its landscape history with that of the Atlas regions. While this Saharan plain

number of textual sources available on the site, and this has considerably hindered fresh reflections upon it. Recently, archaeology has taken over from historical studies. To date, the main archaeological publications on Sijilmāsa are issued from the MAPS (Moroccan-American Project at Sijilmasa), a Moroccan-American archaeological programme directed by Ronald

Messier (MTSU University, Tennessee) that took place between 1988 and 1998. This includes eighteen articles and one monograph, published between 1993 and 2015 (Ronald Messier and James Miller, The Last Civilized Place: Sijilmasa and Its Sahara Destiny [Austin: University of Texas Press, 2015]). But, perhaps because of the academic training of their authors, these archaeological publications remain on the whole very close to topics hitherto developed by historians (including the gold trade, the political history of the city, and the study of monuments mentioned in the texts). Between 2012 and 2018, a new largescale archaeological programme has taken place at Sijilmāsa, under the co-direction of François-Xavier Fauvelle-Aymar (CNRS, France) and Larbi Erbati (INSAP, Morocco). Synthesis publications are now expected.

${ }^{37}$ Chloé Capel, "At the Dawn of Sijilmasa: New Historical Focus on the Process of Emergence of a Saharan State and a Caravan City", in Urbanisation and State Formation in the Ancient Sahara and Beyond, ed. Martin Sterry and David Mattingly (Cambridge: Cambridge University Press, 2020), pp. 594-620.

${ }^{38}$ Jean Margat, Jacques Destombes, and Henri Hollard, Mémoire explicatif de la carte hydrogéologique au 1/50 000 de la plaine du Tafilalt (Rabat: Service géologique du Maroc, 1962), p. 23.

39 Jean Margat, "Les ressources en eau des palmeraies du Tafilalt", Bulletin Economique et Social du Maroc 22/77 (1958): 5-24; Chloé Capel, "Une grande hydraulique saharienne à l'époque médiévale: L'oued Ziz et Sijilmassa (Maroc)", Mélanges de la Casa de Velázquez 46/1 (2016): 139-65.

${ }^{40}$ It is worth mentioning here the recent investigation (2017) by Adam Schneider (University of Colorado, USA) on the possible effects of the Medieval Climate Anomaly (tenth-thirteenth century) in Tāfilallt. In the absence of locally collected proxies, this, like the present study, relies on the exploitation of data taken from the High Atlas range and extrapolated to the nearby Tāfilaltt. Although this study is rigorous and appropriately cautious, it nevertheless has a number of weaknesses: indeed like most studies concerning the Maghrib al-Aqsā, it depends primarily on secondary historical studies, without any historiographical and critical perspective, or reference to primary data (especially archaeological data). As a result, while the climatological conclusion of this article is convincing - that the Medieval Climate Anomaly was felt as an hydric deterioration in Tāfilālt plain - its second, historical, conclusion, - that Almoravid power in the eleventh-twelfth centuries responded to local aridification through the development of a large rural hydraulic system to help oasis agriculture - does not withstand a thorough historical and environmental examination. This has been demonstrated by an archaeological study of the same period that demonstrates the clear pre-Almoravid origin of the hydraulic system of Tāfilālt (Capel, "Une grande hydraulique"). In Schneider's defence, the 


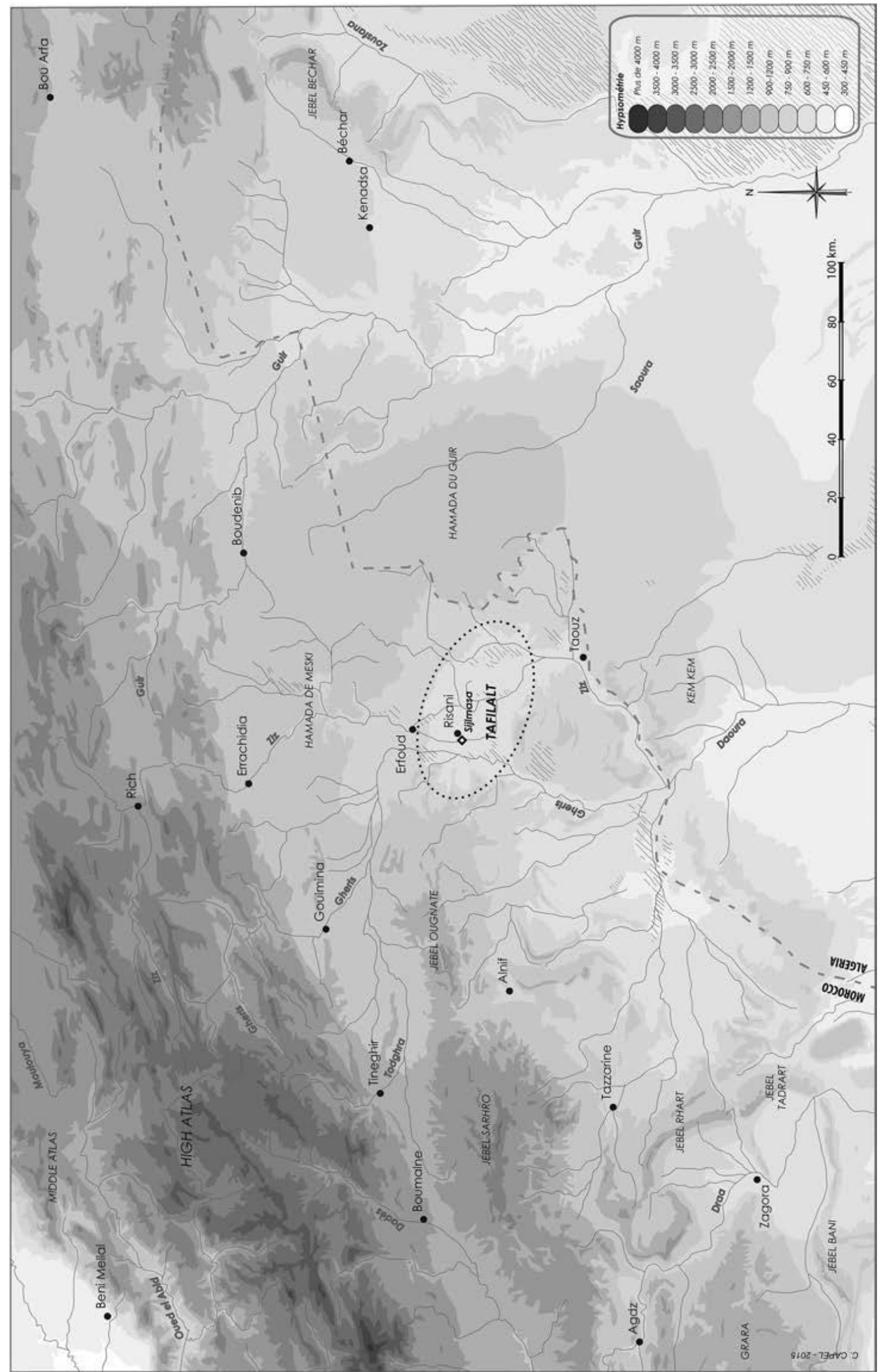

Figure 1. Map of location of Tāfīlālt (C. Capel).

historical misinterpretation developed in his article reproduces the unsubstantiated working hypotheses of the American archaeological team (MAPS) that worked at Sijilmāsa in the 1990s (Adam Schneider, "The Medieval Climate Anomaly as.a Factor in the History of Sijilmasa, Southeastern Morocco", Journal of North African Studies 21 (2016): 132-52). 


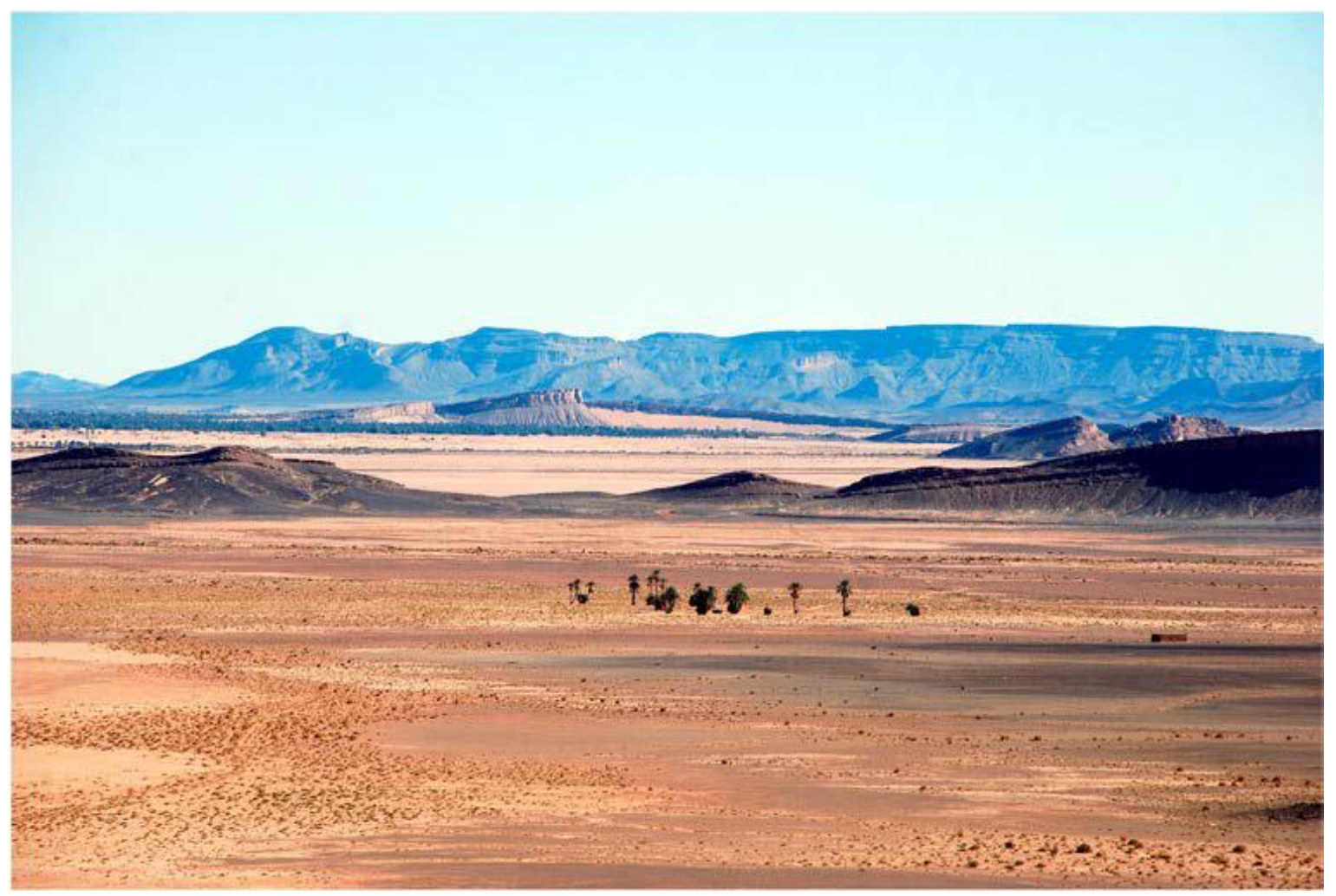

Figure 2. General view of the natural and desert landscapes of Tāilialt plain, limited on all sides by reliefs. This clearly hostile environment is compensated for by both surface and underground abundant water resources, which are exceptional for a Saharan region (C. Capel).

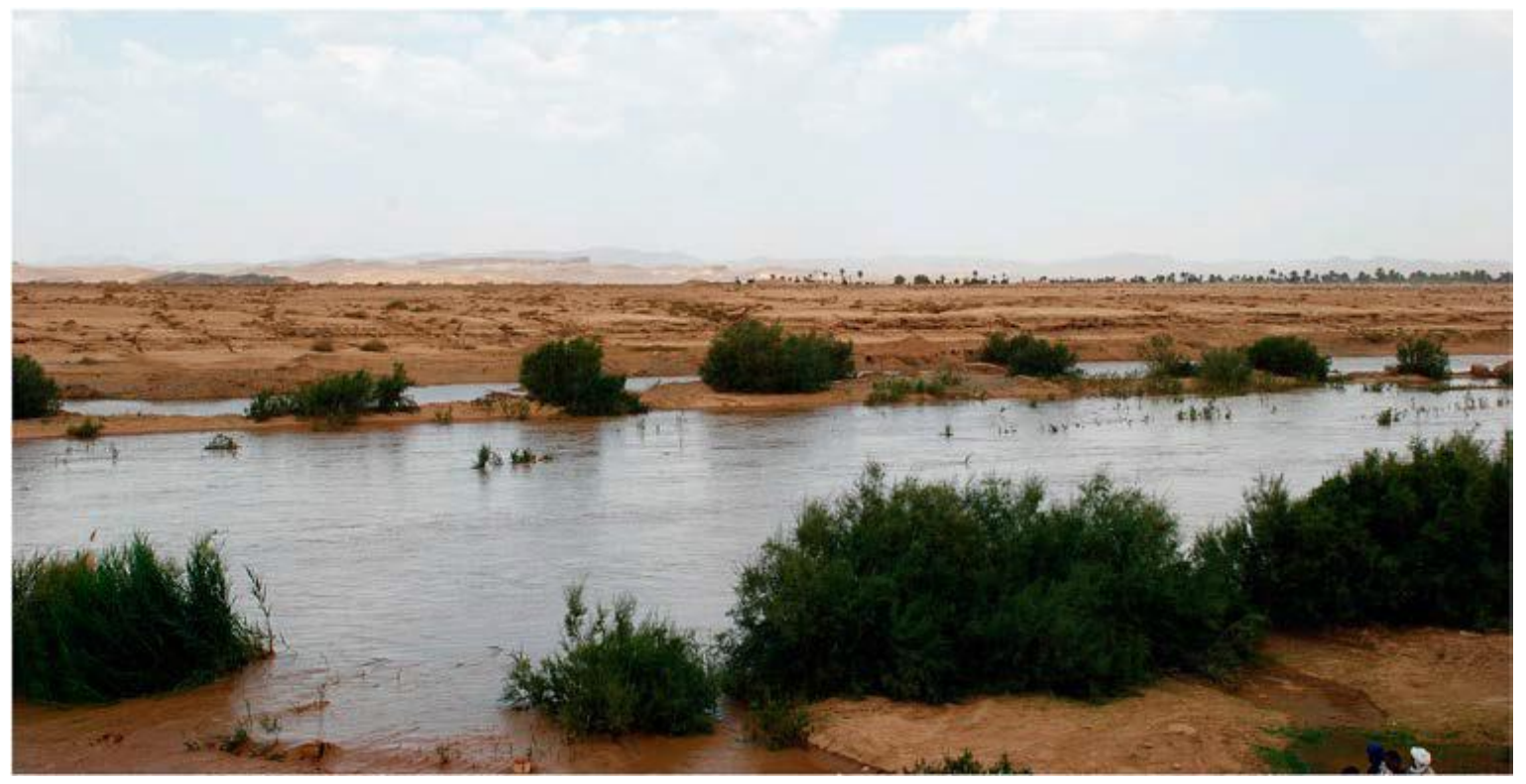

Figure 3. Flood of Wādī Gheris - one of the two main wādīs of Tăfîlālt - during the autumn rainy season. While it is now largely hampered by upstream dams, the impressive flow of the wādī illustrates the privileged nature of the ecological refuge of Tâfílālt (C. Capel). 


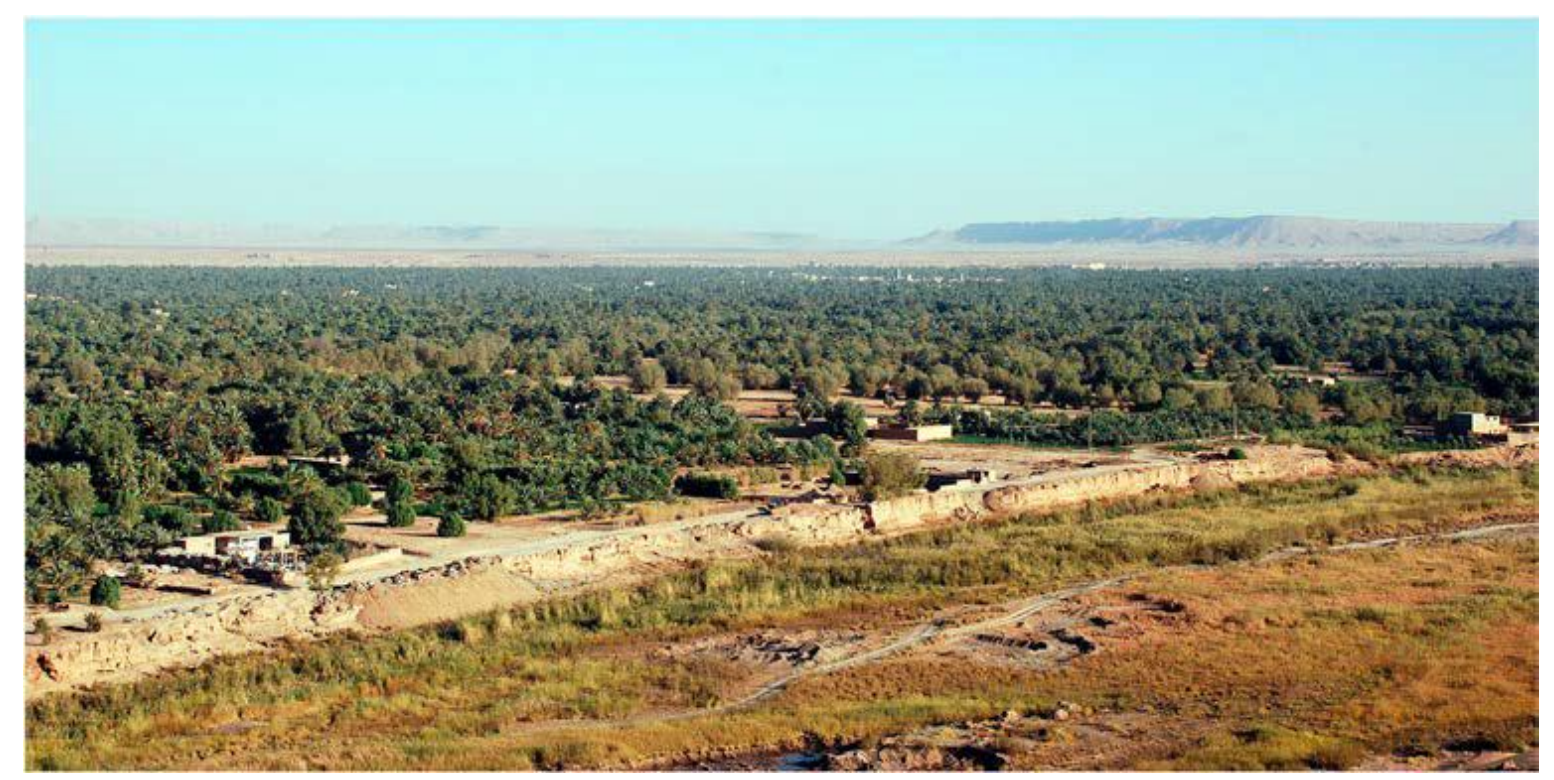

Figure 4. Overview of the oasis landscapes of Tāfilālt. In the foreground, the bed of Wādi Zìz. This image highlights the importance of the anthropic work on desert soils for having developed hundreds of hectares of agricultural land there. Tāfilālt now represents the largest oasis area in Morocco (C. Capel).

is, from a climate point of view, largely subject to continental atmospheric dynamics and is only very marginally affected by the circulation of oceanic air masses - from which it is isolated by the physical barrier of the Atlas range - the vast majority of the water supply to Tâfîlālt comes through a hydrologic network rooted in the Atlas. Consequently, despite its geographical position as a continental plain located $400 \mathrm{~km}$ inland in an undeniably arid environment, the landscape of Tâfîlālt depends entirely on the rainfall regimes affecting the High Atlas and may thus be regarded as an indirect result of the North Atlantic atmospheric circulation. ${ }^{41}$ Although certainly moderated by local modulations, this dependence on the North Atlantic Oscillation suggests that we can apply the climate phasing for northern Moroccan regions to Tāfîlālt, at least in broad terms: a period of aridity at the beginning of the first millennium; a significant increase in humidity until around 1000 , with a short-term arid deterioration between the eighth and the tenth centuries.

If this climate phasing is applicable in Tâfîlālt, what were the direct repercussions of these fluctuations on the environment of Sijilmāsa? Despite having access to significant water resources, Tāfîlālt remains an arid area where ecological balances are fragile and it would therefore have been particularly sensitive to even small climate changes. A sharp aridification would therefore have led to a noticeable loss in vegetation cover and thus have threatened pastoral activities in the region. On the other hand, a local increase in rainfall, either through regularity or abundance, might allow the extension of pasture land and therefore the growth of caprine and camel herds in the region.

\footnotetext{
41 Jean Margat, "Notes sur les cours d'eau pérennes dans les bassins du Ziz et du Rheris", Notes Marocaines 6 (1955): 22-5, p. 24
} 
The impact of hydric variations is more difficult to establish for the river regime of the wādīs. While at first glance it would seem that increasing rainfall upstream could favour a more continuous or more pronounced flow in the wādīs, the influence of other parameters, such as the density of the vegetation cover, the annual distribution of rainfall or the erosive power of the streams, complicates this supposedly linear relationship. In fact, studies carried out in various arid Mediterranean territories subject to similar water fluctuations highlight contrasting environmental effects. Thus, in the lower valleys of the Medjerda (Tunisia) and of the Moulouya (Morocco) river records showing a short-term increase in the frequency and power of the floods have been interpreted - in two different contexts - as the consequence of the emergence of a more arid climate. ${ }^{42}$ Here, the regularity and increase of rainfall, especially in warm periods, led to the development of extensive vegetation cover, which caused a clear retention of water to the detriment of the hydrographic system. During periods of drying and retraction of the vegetation cover, water drainage towards the wādīs was resumed and the water supplies largely transferred to the rivers, which consequently benefited from more abundant and regular floods. Conversely, the opposite conclusion of climatic improvement has been drawn in studies - once again from two different situations - of the middle valley of the Tagus (Spain) and on the eastern Iberian coast, which experienced comparable patterns of multiplication and intensification of flood periods. ${ }^{43}$ In these Iberian examples, the increase of rainfall in autumn and winter periods, poorly absorbed by the vegetation cover, contributed both to increase the volume of water directly drained to the rivers, and to reinforce the spring floods, by forming thicker annual snow cover at higher altitudes.

Which of these two models might be applicable to Tāfîlālt? Here, floods occur at two distinct moments of the year: during autumn rains that water the Atlas foothills and are created during the seasonal negative thrust of the North Atlantic Oscillation, by the meeting between the warm Saharan air masses and the humid oceanic air masses dropping southward; then a few months later, during the spring melting of the Atlas snows, which releases part of the winter rainfall. In the event of a wet optimum, a scenario where spring floods would become more abundant but also more durable is probably to be preferred for Tâfîlālt: indeed, since most of the regional rainfall occurs in winter, the heavy snow accumulation in the Atlas would increase the spring stream in the wādīs, especially the Zīz. An increasing humidity of the climate would then be likely to cause an excess of water, causing more frequent floods and environmental degradation than in a period of lasting aridity. This scenario is confirmed in the Atlantic region by a case study of the Wādī Nūn valley - another Saharan hydrographic network of which the major part of the catchment area is located in the Atlas area - where a period of high fluvial activity dated from the modern era has been associated with a period of increasing humidity. ${ }^{44}$

\footnotetext{
42 Christoph Zielhofer, Jens Bussmann, Hanoun Ibouhouten, and Katrin Fenech, "Flood Frequencies Reveal Holocene Rapid Climate Change (Lower Moulouya River, Northeastern Morocco)", Journal of Quaternary Science 25/5 (2010): 700-14, pp. 701, 712; Dominic Faust, Christoph Zielhofer, Rafael Baene Escudero, and Fernando Diaz del Olmo, "High-Resolution Fluvial Record of Late Holocene Geomorphic Change in Northern Tunisia: Climatic or Human Impact?", Quaternary Science Reviews 23 (2004): 1757-75, p. 1170.

43 José Miguel Ruiz, Pilar Carmona, and Alejandro Pérez Cueva, "Flood Frequency and Seasonality of the Jucar and Turia Mediterranean Rivers (Spain) during the Little Ice Age", Méditerranée 122 (2014): 121-30; Gerardo Benito, Alfonso Sopena, Yolanda Sánchez-Moya, María Machado, and Alfredo Pérez-González, "Palaeoflood Record of the Tagus River (Central Spain) during the Late Pleistocene and Holocene", Quaternary Science Reviews 22 (2003): 1737-56.

44 Julien Mathieu et al., "Holocene Deposits in the Lower Section of the Assaka Wadi, South Morocco: Preliminary Results", Quaternaire 15/1-2 (2004): 207-18, pp. 215-16.
} 
The influence of aridification on autumnal floods remains difficult to characterise in the absence of local sedimentological studies. Several options are possible: a rarefaction of floods and their volume; a rarefaction of floods correlated to an increase of their flow; or an increase in the frequency of floods but with a decrease in the average flow. These three scenarios depend on the seasonal distribution of precipitation, the nature of the upstream vegetation cover, and the size of the affected geographical basin. The likely behaviour of autumnal floods is therefore more difficult to interpret without further analysis of the fluvial deposits of Tâfîlālt.

Applying these interpretations to the Moroccan climate model, it seems likely that the environment of Tāfîlālt changed significantly over the course of the first millennium. The period of humidity identified between the third and seventh centuries probably favoured the expansion of the vegetation cover in Tâfilalt. It would have also increased the flow and the duration of spring floods, and may thus have contributed to an increase in sedimentation downstream of the plain and to the multiplication of ponds in the natural divagation zones of wādīs Zīz and Gheris. Around the middle of the eighth century, this period was interrupted by a sequence of clear drying that may have temporarily destabilised the water balance of the plain for a century or so: the vegetation cover may have retracted to the wādi beds, the water table may have retreated and the surface water traps may have disappeared. However, despite a reduced flow rate and/or frequency of the $\mathrm{Z} \overline{\mathbf{1}} \mathrm{z}$ and Gheris floods, flooding would probably have remained regular and continued to bring a large volume of water to the region, even as the two wādis experienced more marked periods of low water levels, perhaps even drying up during the driest months.

\section{Correlation between the eighth-ninth-century climate anomaly and the historical framework of Täfilalt: a proposal}

Connecting the history of societies to the history of climates is the final stage of historical climatology. The fragile environment and economic balance in Tâfìlālt must have been affected by the climate fluctuations in northern Morocco and the Atlas, which must have led in turn to side-effects in the organisation of society. It is conspicuous in this context that the foundation of Sijilmāsa coincides with the start of the climatic arid deterioration episode of the eighth-ninth centuries.

Historical tradition dates the origin of the famous medieval caravan city to the beginning of the eighth century. According to the eleventh-century Andalusian historian al-Bakrī - the only source that describes the foundation of the city - Sijilmāsa was established in $757-758$ by a Muslim proselytising movement that gathered together a core of believers from scattered and isolated Saharan pastoral communities around a shepherd who had become a preacher. ${ }^{45}$ The rise of Sijilmāsa is best viewed as a local manifestation of a wider upheaval that affected the whole Maghrib al-Aqșā. In this period, the area witnessed both a widespread adoption of Islam - first introduced in the region towards the end of the seventh century - and a dynamic of political renewal. The latter was reflected in the foundation of multiple Muslim polities (the Salinids in 709, the Barghwata in 744, the Idrīsids in 789) and the development of new large urban centres (Nakūr, Fās, Āghmat). Initially established as an egalitarian elective imamate, the religious and

\footnotetext{
${ }^{45}$ Al-Bakri, Description de I'Afrique septentrionale, ed William Mac Guckin de Slane (Paris, Librairie d'Amérique et d'Orient Adrien Maisonneuve, 1965), pp. 148-152 (ed.), pp. 282-290 (trans.)
} 
political movement born at Tâfīlālt evolved within a few decades into a dynastic system, through which the clan of the Banū Midrār (the Midrārids) retained power for around two centuries. In the same period, the city and oasis of Sijilmāsa became the main caravan stopover on the route between North Africa and West Africa. Little or nothing is known about the pre-Islamic history of the region, although it was already populated in Antiquity, as reflected by the many funerary sites and settlements scattered around Sijilmāsa and more widely throughout southern Morocco. ${ }^{46}$ Recent research carried out in the neighbouring valleys of Wādī Nūn ${ }^{47}$ (1995-2005) and Wādī Dra ' a ${ }^{48}$ (2015-2018) confirms the existence of populations occupying, controlling and exploiting some Saharan wetlands before the upheavals of the eighth and ninth centuries, but this research has not yet illuminated the modus vivendi of these societies in detail. My own recent work has proposed that the origins of Sijilmāsa arose less from exogenous religious dynamics than from economic and social factors that were already present before the introduction of Islam. ${ }^{49}$ I have also argued that Sijilmāsa was not the consequence of gradual growth around a nucleus of settled shepherds, but rather the result of an ambitious collective and political decision taken in the early years of the ninth century to found a new town from scratch to replace several older settlements in the vicinity. ${ }^{50}$ Whatever the actual phases of its development, Sijilmāsa soon became not only a vital stopover for caravans involved in trans-Saharan trade, but also, as early as the tenth century, a major mint in the Maghrib al-Aqșā as a large number of medieval dinars, whose high quality has been proven by archaeology, were produced there from gold imported from sub-Saharan Africa. ${ }^{51}$ The foundation and subsequent development of Sijilmāsa thus had considerable implications for the political, economic, social and environmental balances both in Tāfîlālt and across the whole western Maghrib.

In the eighth-ninth centuries, many global factors explain the emergence of Sijilmāsa: ${ }^{52}$ the rise of Muslim proselytism in Maghrib; the destabilisation of the central authorities of Kairouan through political and religious dissent; the dynastic transition taking place in the east between the Umayyads and the 'Abbāsids; the reinforcement of Arab armies and of Arab groups in North Africa; and the emergence of trans-Saharan trade

\footnotetext{
${ }^{46}$ Youssef Bokbot, "Habitats et monuments funéraires du Maroc protohistorique", PhD Thesis, Aix-en-Provence University, 1991.

47 Youssef Bokbot, Jorge Onrubia-Pintado, and Abdallah Saleh, "Néolithique et protohistoire dans le bassin de I'oued Noun (Maroc présaharien): Quelques données préliminaires", in Actes du Premier Colloque de Préhistoire Maghrébine, volumes I-II (Algiers: Centre National de Recherches Préhistoriques, Anthropologiques et Historiques, 2011), II: 305-21.

${ }^{48}$ David Mattingly, Youssef Bokbot, and Martin Sterry, "The Middle Draa Project (Morocco): Results from the Survey and Trial Excavations 2015-18", Libyan Studies 50 (2019): 73-80.

${ }^{49}$ Chloé Capel and Abdallah Fili, "La fondation de Sijilmâsa: Réexamen historique et découvertes archéologique", HespérisTamuda 51/1 (2016): 39-82; eisdem, "Sijilmâsa au temps des Midrârides: Nouvelles approches historiques et premier bilan archéologique", in L'ibadisme dans les sociétés de l'islam médiéval, ed. Cyrille Aillet (Berlin: De Gruyter, 2018), pp. 137-68.

${ }^{50}$ Chloé Capel, "Sijimassa in the Footsteps of the Aghlabids: The Hypothesis of a Ninth-century New Royal City in Tafilalt Plain (Morocco)", in The Aghlabids and Their Neighbours: Art and Material Culture in 9 -century North Africa, ed. Glaire D. Anderson, Corisande Fenwick, and Mariam Rosser-Owen [Handbook of Oriental Studies. Section one: The Near and Middle East, volume CXXII] (Leiden: Brill, 2018), pp. 531-50.

${ }^{51}$ Ronald Messier, "Quantitative Analysis of Almoravid Dinars", Journal of the Economic and Social History of the Orient 23/1-2 (1980): 102-18, p. 109; idem, "The Almoravids: West African Golds and the Gold Currency of the Mediterranean Basin", Journal of the Economic and Social History of the Orient 17/1 (1974): 31-47, pp. 38-9; Caroline Roux and Maria Filomena Guerra, "La monnaie almoravide: De l'Afrique à l'Espagne", Revue d'Archéométrie 24 (2000): 39-52, pp. 43-4.

${ }^{52}$ Capel and Fili, "Fondation de Sijilmâsa"; eisdem, "Sijilmâsa au temps des Midrarides"; Capel, "Sijilmasa in the Footsteps of the Aghlabids"; Capel, "At the Dawn of Sijilmasa".
} 
in the central Maghrib. ${ }^{53}$ As a consequence, the founding of the city cannot be attributed solely to the changing climate; yet the impact of environmental data must be taken into consideration to explain, if not the mechanism of the birth of the city, then at least its timing, its location and the manner in which it developed.

The emergence of a sedentary and agricultural settlement in response to a climatic, and especially hydric, degradation in a semiarid to arid environmental context is not unusual. Archaeologists have documented several similar Saharan and Middle Eastern examples in other periods, where pastoral populations concentrated and sedentarised around ecological niches similar to those at Tâfîlālt. These include the Neolithic villages of Dhar Tichitt (Mauritania) and the agricultural settlements of the Niger Bend, particularly the Yame valley (Dogon country) of the second millennium BC. ${ }^{54}$ It is thus entirely possible that a largescale urban settlement (Sijilmāsa) and a large-scale agricultural area (the Tāfîlālt Oasis) could have been created in Tâfîlālt around the eighth century because the conditions for the pastoral life in this arid region - but also in the surrounding areas - had considerably deteriorated in a few decades due to a thinning of the vegetation cover and the disappearance of water points. Thereafter, people may have been forced to gather in more protected areas, such as the plain of Tâfĩlāt, which represented a true haven of humidity in the Sahara. Relatively rapidly, high demographic concentration and increasingly challenging environmental saturation may have led people to adopt major changes in their way of living and ushered in a new agricultural era through irrigation.

The development of irrigated agriculture at Tâfîlālt, in effect the creation of the oasis of Tâfîlālt, dates from the Islamic period and accompanies the foundation of Sijilmāsa, as I have argued elsewhere. ${ }^{55}$ But agriculture in the plain probably predated irrigation as the natural environmental conditions of Tâfîlālt would have allowed flood recession farming ${ }^{56}$ without any help from irrigation, especially if the climate of Late Antiquity was wetter. This may have encouraged the development of small seasonal villages in Tâfîlālt before the foundation of Sijilmāsa, and the settlement of groups involved in livestock breeding and agriculture before the establishment of the Midrārid imamate. A similar, contemporary dynamic has recently been identified in the nearby Dra'a Valley, which would support this argument. ${ }^{57}$ But urban development on the scale of that of Sijilmāsa could only be supported by a transition to a surplus agriculture economy. This stage thus required an intensive programme of landscape development, which involved the introduction of irrigated agriculture. This happened at some point between the eighth and ninth centuries, when the inhabitants of Tāfīlālt came together to deliberately lay out a gigantic agricultural zone thanks to the excavation of a centralised irrigation system. ${ }^{58}$

\footnotetext{
53 Philippe Sénac and Patrice Cressier, Histoire du Maghreb médiéval, VII -X I siècle (Paris: Armand Colin, 2012).

${ }^{54}$ Sylvie Amblard-Pison and Alain Person, "Relations chronologiques entre habitats, mode de vie et fluctuations climatiques holocènes sur les Dhars Tichitt et Oualata (Mauritanie sud-orientale)", $14 \mathrm{C}$ et Archéologie: Actes du 3ème congrès international. Lyon, 6-10 avril 1998, ed. Jacques Evin, Christine Oberlin, Jean-Pierre Daugas, and Jean-François Salles (Paris: Société Préhistorique Française, 1999), pp. 355-9; Sylvain Ozainne, "Pulsations sahariennes et premiers cultivateurs: Le néolithique récent du plateau Dogon (3500-500 av. J.-C.)", Etudes Maliennes 65 (2006):69-88, pp. 80-2.

${ }^{55}$ Capel, "Une grande hydraulique".

${ }^{56}$ Chloé Capel, "Colonisation agricole et anthropisation oasienne des marges désertiques du Maghreb à l'aube de l'époque médiévale: Le cas du Tafilalt et de Sijilmassa", in Vivre à la frontière: Les sociétés du prédésert d'Afrique du Nord et du Sahara. Antiquité, moyen-âge, ed. Stéphanie Guédon (Bordeaux: Ausonius, 2020 forthcoming), pp. 103-122.

${ }^{57}$ Mattingly, Bokbot, and Sterry, "Middle Draa Project".

${ }^{58}$ Capel, "Une grande hydraulique".
} 
Composed of a main channel and a network of secondary channels arranged in a herringbone pattern (see Figure 5) and feeding independent lands, the oasis structure was thus based on a collective, equitable and egalitarian hydraulic system. As Paul Pascon theorised in his analysis of mid-twentieth-century agrarian systems of the Haouz region, this rigorous territorial grid could be understood as a physical manifestation of the tribal allotment of agricultural parcels, each associated with the allocation of water exploitation rights. ${ }^{59}$ In this view, the strict division of a territory in hydraulic terms might carry social indicators and would reflect whole sections of the organisation of a human group. Pascon thus considers irrigated territory as both a technical unit and a unit of human geography. ${ }^{60}$ The hydraulic system of Tâfīlālt, like most oasis systems, consequently prevented possible conflicts amongst the urban community of Sijilmāsa. Upstream territories are generally better watered but also smaller, because their extension is limited by the presence of their neighbours, while downstream territories can expand and are in fact generally much larger, but have lower humidity and thus a lower yield. The balances are thus maintained.

Reflection on the earliest irrigation system of Tāfilālt thus provides valuable information on the settlement organisations in this region at the dawn of the Islamic era and on the nature of the social authority that governed this community. ${ }^{61}$ Most likely driven by environmental imperatives in the acquisition of local natural resources that might otherwise have led to competition and social tensions, inhabitants of Tāfīlālt transformed their relationship with the environment by implementing a system of water exploitation that was a common good. This system demanded a horizontal balance of power between the different groups of the community and was made possible only by a rational organisation of rights over water. In other words, water management reveals a rigorous political structure in Tâfīlālt, based on community solidarity and egalitarianism in the appropriation of agricultural lands. Authority here was not manifested by a vertical state organisation or by an ascendency of tribal origin, but by overall cooperation, although it is not known whether this was also apparent in other aspects of society. The need to implement such a structure was probably due to a major issue: the survival of the group, because without rational water management, the oasis of Tâfîlālt and its dense population centre could not have survived.

The economic, political and demographic reality of the caravan city is still largely unknown to researchers because of the lack of written or material evidence. It is therefore difficult to reconstruct the processes that led to the development of Tāfîlālt at the dawn of the medieval era. ${ }^{62}$ However, the egalitarian and horizontal management of the original hydraulic system of Tâfîlālt is surprisingly consistent with the social and religious organisation described in al-Bakrī's foundation myths of the city. In his account, Sijilmāsa was considered to have been founded as a Muslim imamate respecting the Sufi dogma. Among other things, this advocated the equality of believers before God, whatever

\footnotetext{
59 Paul Pascon, Le Haouz de Marrakech, volumes I-II, (Rabat: Editions Marocaines et Internationales, 1983), I:84-98.

60 Pascon, Le Haouz de Marrakech, I:84-5.

${ }^{61}$ Chloé Capel, "Histoire hydraulique et histoire urbaine en Islam: Lorsque l'étude archéologique des réseaux d'irrigation d'un terroir éclaire les dynamiques de peuplement d'une ville. Emergence, développement et transformation de la cité oasienne de Sijilmassa (Maroc)", Hespéris-Tamuda 55/1 (forthcoming).

${ }^{62}$ Chloé Capel, "At the Dawn of Sijilmasa: New Historical Focus on the Process of Emergence of a Saharan State and a Caravan City", in Trans-Sahara Project: Urbanisation and State Formation, ed. David Mattingly, Martin Sterry, Chloe Duckworth, Victoria Leitch, and Aurélie Cuenod (London: Society for Libyan Studies, 2020), pp. 594-620.
} 


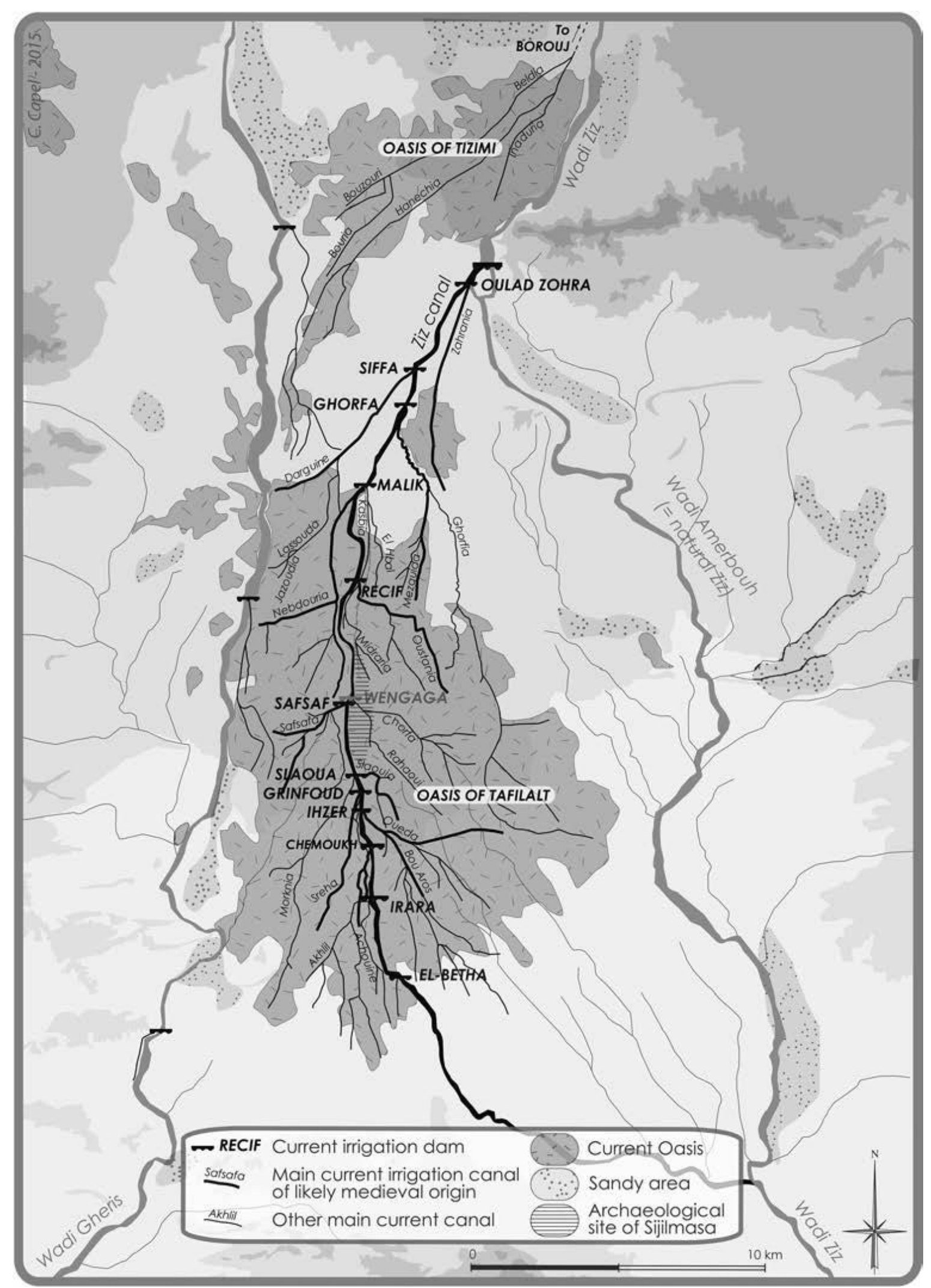

Figure 5. Map of the current irrigation network of Tāfīlallt, largely built on a scheme set up in medieval times, even before the foundation of Sijilmāsa (in the centre of the oasis), whose location is based on it (C. Capel). 
their social, tribal or cultural origins; political power was exercised collectively by an assembly of wise men who elected the fairest of its members at its head. This religious egalitarian view was considered as dissident by the 'Abbāsid Caliphate, but could partly explain the success of this dogma among the North African populations and shed light on the reasons for the fairly rapid and widespread adoption of the new religion during the eighth century. The historical view that Sijilmāsa was born in a political system free from family, ethnic or economic constraints remains strong today, ${ }^{63}$ and may be confirmed in part by the analysis of the hydraulic systems created by this society.

\section{Conclusion: Authority beyond state and tribe: environmental pressure and water management at the heart of the Maghrib political structures in the early Middle Ages}

The case study of the climate, environment and settlement of the Tâfîlālt plain highlights that Sijilmāsa and its oasis may have been created under the pressure of a climate deterioration that forced the inhabitants of the region to evolve their way of life and to reconsider their subsistence economies. This profound social change had repercussions on political organisation: the emergence of intensive irrigated agriculture through the foundation of the oasis can be interpreted as a response to the environmental crisis, which created the need for collective and concerted management of the common good that is water. Although political, religious and commercial factors also contributed to the development of Sijilmāsa, the climate deterioration of the eighth-ninth centuries would have had a significant impact on the evolution and restructuring of chains of authority. The climate factor may thus not fully explain why Sijilmāsa was founded, but could bring many answers to the questions: "Why precisely here and at this time?"

Is it now possible to transpose this case study to the scale of the entire western Maghrib? Did the climate fluctuation of the eighth-ninth centuries cause a major water shortage that forced societies to concentrate around ecological refuges, develop irrigated agriculture and then to start an economic transition leading to specialised and urban activities? Should we seek environmental factors behind the political, economic and social impulses that shaped the foundation of $\bar{A}$ ghmat, Fās or even Nakūr, as well as Sijilmāsa? Was the foundation of Āghmāt on the banks of the Wādi ūrîka and the implementation of its irrigated land a response to a substantial aridification of the Haouz region? Might the movement of the inhabitants of Volubilis to the well-irrigated Wādī Fās have been motivated by the search for a sustainable and reliable water source while the Wādi Khouman and the Zehroun springs were drying up? Should the establishment of the Salīhids' capital of Nakūr and its vast irrigated hinterland - which only occurred many decades after the apparent establishment of the emirate in $709-$ be regarded as a response to unprecedented environmental constraints? All these questions remain unanswered for the moment and demand further environmental and climatic studies across the western Maghrib. In the meantime, specialists might consider this new element - a climatic arid episode of the eighth to ninth centuries - in their future analyses.

\footnotetext{
${ }^{63}$ Capel and Fili "La fondation de Sijilmâsa"; eisdem, "Sijilmâsa au temps des Midrârides".
} 